Georgia State University

ScholarWorks @ Georgia State University

$11-1-2015$

\title{
Impact of Allowing Sunday Alcohol Sales in Georgia on Employment and Hours
}

Julie L. Hotchkiss

Federal Reserve Bank of Atlanta, julie.I.hotchkiss@atl.frb.org

Yanling Qi

California State University, Long Beach, Yanling.Qi@csulb.edu

Follow this and additional works at: https://scholarworks.gsu.edu/uwrg_workingpapers

\section{Recommended Citation}

Hotchkiss, Julie L. and Qi, Yanling, "Impact of Allowing Sunday Alcohol Sales in Georgia on Employment and Hours" (2015). UWRG Working Papers. 92.

https://scholarworks.gsu.edu/uwrg_workingpapers/92

This Article is brought to you for free and open access by the Usery Workplace Research Group at ScholarWorks @ Georgia State University. It has been accepted for inclusion in UWRG Working Papers by an authorized administrator of ScholarWorks @ Georgia State University. For more information, please contact scholarworks@gsu.edu. 


\section{W. J. Usery Workplace Research Group Paper Series}

Working Paper 2015-11-1

November 2015

\section{Impact of Allowing Sunday Alcohol Sales in Georgia on Employment and Hours}

Julie L. Hotchkiss

Federal Reserve Bank of Atlanta

Yanling Qi

California State University, Long Beach

\section{AndRew Young SchoOL}




\title{
Impact of Allowing Sunday Alcohol Sales in Georgia on Employment and Hours
}

\author{
Julie L. Hotchkiss \\ Federal Reserve Bank of Atlanta \\ Georgia State University \\ 1000 Peachtree St. NE \\ Atlanta, GA 30309 \\ 404-498-8198 \\ Julie.L.Hotchkiss@atl.frb.org \\ Yanling Qi \\ California State University, Long Beach \\ 1250 Bellflower Blvd \\ Long Beach, CA 90840 \\ Yanling.Qi@csulb.edu
}

November 17, 2015

\begin{abstract}
This paper uses differential timing across counties of the removal of restrictions on Sunday alcohol sales in the state of Georgia to determine whether the change had an impact on employment and hours in the beer, wine, \& liquor retail sales industry. A triple-difference analysis finds significant increases in average weekly hours in the treated industry. Since there is no significant employment increase, it appears that employers adjusted to remaining open one additional day per week by increasing hours of existing employees, rather than by hiring additional workers.

JEL classification: C21, J23, L89, L38
\end{abstract}

\footnotetext{
Corresponding author. The views expressed here are not necessarily those of the Federal Reserve Bank of Atlanta or the Federal Reserve System. An enormous amount of gratitude is extended to Jacqueline Byrd of the Georgia Food Industry Association and her significant efforts in coding all outcomes for Sunday alcohol sales referendums for all municipalities in Georgia. Comments from Monica Deza and participants in the Georgia State University HERU workshop are also greatly appreciated. Appreciation is also extended to the Georgia Department of Labor for making the data available necessary for the analysis available for confidential research purposes. Early, excellent research assistance was provided by Fernando Rios-Avila.
} 


\section{The Impact on Employment and Hours of Allowing Sunday Alcohol Sales in Georgia}

\section{$\underline{\text { I. Introduction and Background }}$}

Different counties and municipalities in Georgia started allowing sales of alcohol on Sundays as early as November 13, 2011. Laws prohibiting the sale of alcohol on Sundays are commonly referred as "blue laws" and have existed in the United States since colonial times. When Prohibition was repealed in 1933, several states, including Georgia, opted to retain Sunday sales restrictions. During the 2011 legislative session, Georgia legislators voted to allow counties and cities to determine whether grocery, convenience, and liquor stores could sell alcohol on Sundays. As of the 4th quarter of 2013, 53 unincorporated counties $(33.3 \%)$ and 174 cities $(33.9 \%)$ had held referendums in order to allow alcohol sales on Sunday. At the time the bill was passed, Georgia was only one of three remaining states in the U.S. with blue laws on the books (Indiana and Connecticut were the other two).

In the debate surrounding the pros and cons for blue laws, discussion of traffic accidents and the potential boon to state coffers seemed to be just as important as any moral or biblical concerns (for example, see Jenkins 2011, Bonner 2011, Guntzel 2011, and AP Reports 2011), although one study found a 15 percent decline in church attendance in states where blue laws have been repealed (Gruber 2008). In addition, a 2012 report by the Centers for Disease Control and Prevention (see Weir 2012) reviewed the literature relating traffic accidents, domestic disturbances, and outdoor assaults to restrictions of Sunday alcohol sales: traffic fatalities increased when restriction were removed and domestic disturbances and outdoor assaults declined when restrictions were enacted.

This paper deviates from these concerns about traffic fatalities, state revenues, and salvation to focus on the labor market impact of the repeal of the Sunday alcohol sales 
restrictions in the state of Georgia. We make use of administrative data that the Georgia Department of Labor uses to administer the state's Unemployment Insurance Program. These data are historically referred to as ES202 data and are the data used to produce the U.S. Bureau of Labor Statistics' Quarterly Census of Employment and Wages (QCEW). The advantage of using the actual administrative data is that this analysis is not constrained by data suppression rules imposed on the public version of the QCEW. We are able to take advantage of the differential timing of implementation across counties and municipalities to perform a tripledifference type of analysis of changes in employment and weekly earnings in NAICS (North American Industry Classification System) code 4453 (beer, wine, \& liquor stores), relative to employment and weekly earnings changes in other industries, in counties that passed a sales referendum compared to those changes in counties that did not pass a referendum. Since there is no reason to expect this law change would affect hourly wages of liquor store sales clerks and stockers, the weekly earnings analysis can tell us something about changes in relative hours of those workers.

It is possible that extending the window of opportunity to purchase alcohol will increase alcohol sales, thus increase demand for workers and/or workers' hours to tend stores to meet this greater demand. It is also possible that adding hours on Sunday will merely shift alcohol purchases from another day of the week to Sunday, not raising total sales, or labor demand in this industry at all. There is some evidence for the later possibility from Carpenter and Eisenberg (2009) find that while the expansion of alcohol sales to Sunday (in Canada) significantly increased the amount of drinking on Sunday, it did not increase overall total alcohol consumption. We do not have consumption data to be able to distinguish increases or shifts in consumption across days. However, unless liquor store owners merely shift their day of closure 
in response to the removal of sales restrictions on Sundays, an extra day of business will require additional staff. It's unclear, however, if additional staff is needed, whether the adjustment would be made on the extensive (additional workers) or the intensive (additional hours) margin. In fact, we find evidence that liquor store owners increased the average hours of their workers, but did not significantly increase the number of workers over this period. This suggests that even if alcohol purchases shifted from one day of the week to another, liquor store owners chose not to forego an additional day of potential sales by merely shifting the day of closure.

\section{The Data}

\section{A. Georgia Department of Labor Employment and Wage Data}

For the purposes of administering its Unemployment Insurance program each state requires employers to file a quarterly report with the state Department of Labor detailing all wages paid to workers who are covered under the Social Security Act of 1935. These data provide an almost complete census of firms in the state, covering approximately 99.7 percent of all wage and salary workers (Committee on Ways and Means, 2004). The firm-level information identifies the firm's county, six digit NAICS, number of employees, and total wage bill for each quarter. These data provide the foundation for the U.S. Bureau of Labor Statistics' Quarterly Census of Employment and Wages (QCEW), which is publicly available.

Ideally, one would be able to analyze changes in employment and total wages paid at the firm level, however only aggregated data at the industry/county level for each quarter has been made available to us. Nonetheless, these data do offer a significant advantage over the publically 
available QCEW data since they are not subject to the data suppression rules imposed by the BLS for release of the QCEW. ${ }^{1}$

The focus of this paper, of course, is employment and earnings in the beer, wine, \& liquor stores (NAICS $=4453$ ) retail industry. This is the industry we would expect to be most affected by the removal of restrictions on Sunday alcohol sales, hence this is the treated industry. All other non-retail industries will be used as the control -- those not expected to be affected by the Sunday sales referendums. Other (non-liquor store) retail will be used for various falsification tests. However, NAICS industries 4451 (grocery stores), 4452 (specialty food stores), 4471 (gasoline stations), 4529 (other general merchandise stores), 1029 and 9999 (not otherwise classified) are excluded from all analyses to make the distinction between treated and control industries as clean as possible -- 4451, 4452, 4471, and 4529 correspond to retail establishments that may or may not sell alcohol and are likely to have already been open on Sundays.

\section{B. Data from the Georgia Food Industry Association}

The dates on which different counties and municipalities held referendums on the sale of alcohol on Sunday were obtained from the Georgia Food Industry Association (GFIA). The data provided by the GFIA include information for all 159 counties and 513 cities in the state of Georgia. The data contain information on whether a referendum was held (or not), the outcome (passed/failed with actual vote count), and, if passed, the effective date (when sales could begin). County geography provides another dimension across which the analysis is performed. For example, while we would expect industry 4453 to be most affected by the removal of sales restriction, we would not expect liquor stores in counties that did not pass the referendum to be affected, only those located in counties that removed the sales restrictions.

\footnotetext{
${ }^{1}$ We would be subject to those suppression rules if we wanted to report county/industry details of employment and wages, but the unsuppressed data can be used without restriction for regression analysis.
} 


\section{Data from OnTheMap}

Since we only have county level industry employment and earnings data available to us, we need to establish whether a particular county allowed alcohol sales and when sales began. However, since each county and city could hold separate referendums, it is not uncommon for the vote in the unincorporated part of the county to have gone one way and the vote in one or more cities within the county to have gone the other way. Note that a county vote only covers establishments within the unincorporated area of the county -- the vote does not apply to cities within the county; they have to hold their own, separate referendum. In order to make a determination of whether a particular county should be considered "treated" (allowing Sunday alcohol sales) or "control" (not allowing sales), we use the following rules (see Figure 1 for an illustration):

a) For a county that did not hold the referendum or failed to pass the referendum where all the cities within the county never held or passed the referendum, it is classified as a control county.

b) For a county that passed the referendum where all the cities within the county also passed the referendum, it is classified as a treated county. The effective date of the referendum for the county is assigned by determining which effective date (among county and municipality effective dates, if different), ordered chronologically, covered at least 50 percent of total employment within the county. ${ }^{2}$ We made use of the U.S. Census Bureau online tool OnTheMap.com (http://onthemap.ces.census.gov/) to collect 2011 employment levels for all municipalities and counties.

\footnotetext{
${ }^{2}$ Butts county provides an example of this procedure. The county (effective date is 2012Q2; employment $=5,695)$ and cities Flovilla (2013Q4; employment = 21), Jackson (2011Q4; employment = 3,353), and Jenkinsburg $(2011 \mathrm{Q} 4$; employment $=205)$ passed the law. The employment percentage represented in Jackson and Jenkinsburg is $62.5 \%$ of all employment in the county, so 2011Q4 was designated as the effective date for Butts County.
} 
c) For a county that did not hold or pass the referendum that contains some cities that did pass the referendum, or for a county that passed the referendum but contains some cities that did not hold or pass the referendum, we also have to compare employment within those cities to make a county-wide determination. If the cities that conflict with the county vote contain at least 50 percent of the county's employment, then determination is based on the city outcomes, with an effective date (if different across cities) being determined as described above. And, vice versa if the total employment of the conflicting cities does not add up to at least 50 percent of total county employment. ${ }^{3}$

[Figure 1 about here]

Finally, we end up coding 93 counties as controls that either never held or failed to pass the referendum, and 66 counties as treated, with effective dates between 2011Q4 to 2013Q1, 2013Q4 and 2014Q1. Figure 2 shows a map of Georgia with each county shaded based on the year in which the county is classified as having removed alcohol sales restrictions.

[Figure 2 about here]

Alternative strategies for classifying counties as having removed or not removed sales restrictions were considered and rejected. For example, one could classify a county as removing restrictions if any entity (any city, no matter how small, or the unincorporated portion of the county) removed sales restrictions. This would be a very weak classification scheme. Alternatively, one could require that all entities (all cities plus the unincorporated portion of the county) pass referendums before classifying the county as having removed sales. This would be

\footnotetext{
${ }^{3}$ For example, the referendum in unincorporated Peach County (employment $=8,242$ ) failed, while both cities within Peach County passed the law. Byron (employment $=1,746)$ passed it with an effective date 2011Q4, and Fort Valley (employment $=4,216$ ) passed it with an effective date of 2013Q4. Therefore, we assign Peach County as a treated county since employment percentage of passed cities is $72.3 \%$. The effective date is determined by Fort Valley, since employment in passed jurisdictions doesn't reach 50 percent until the later effective date of Fort Valley.
} 
an excessively stringent classification scheme. We provide results showing that our results are robust to these extreme classification schemes.

\section{Sample Means}

Table 1 contains sample means by treated industry (beer, wine, \& liquor stores), treated county (whether the county removed sales restrictions or not), and treated time period (after the referendum became effective). Control industry includes the averages across all non-retail industries. A number of observations stand out as differentiating these different treatment and control groups. Counties that removed Sunday sales restrictions are considerably larger than counties that did not. This can be seen in the large average industry employment both in beer, wine, \& liquor stores and in all other industries in treated counties relative to control counties. The lower unemployment rates, higher labor force participation rates, and higher average weekly earnings in counties removing Sunday sales restrictions also suggests a more urban environment, hence greater population. The other differences in characteristics (e.g., percent black or Hispanic) also likely reflect differences in county population sizes and urbanization. The size differences in employment, earnings, and population levels across treatment categories suggest that performing the analysis using logs (rather than levels) and weighting by county size (population) will be important.

[Table 1 about here]

\section{Methodology}

The analysis is structured as a standard triple-difference (DDD) model: (1) all industries are included in the analysis, with the treated industry being beer, wine \& liquor retail stores 
(NAICS 4453$) ;{ }^{4}(2)$ all counties are included in the analysis, those that did pass the sales referendum, and those that did not; and (3) there are both pre- and post-effective date observations for all industries and counties. ${ }^{5}$ Hence, the triple-difference structure.

The basic estimating equation for log employment takes the following form (analysis of log average weekly earnings is analogous):

$$
\begin{aligned}
& \ln E_{i c t}=\alpha+\beta_{1} \text { Treat }_{i}+\beta_{2} \text { Pass }_{c}+\beta_{3} \text { Post }_{c t} \\
& +\gamma_{1} \text { Treat }_{i} \text { Pass }_{c}+\gamma_{2} \text { Treat }_{i} \text { Post }_{c t}+\gamma_{3} \text { Pass }_{c} \text { Post }_{c t}+\gamma_{4} \text { Treat }_{i} \text { Pass }_{c} \text { Post }_{c t} \\
& +\theta_{1} t \times \text { Treat }_{i}+\theta_{2} t \times \text { Pass }_{c}+\theta_{3} t \times \text { Post }_{c t} \\
& +\theta_{4} \text { t } \text { Treat }_{i} \text { Pass }_{c}+\theta_{5} \text { t } \text { Treat }_{i} \text { Post }_{c t}+\theta_{6} \text { t } \text { Pass }_{c} \text { Post }_{c t}+\theta_{7} \text { t } \times \text { Treat }_{i} \text { Pass }_{c} \text { Post }_{c t} \\
& +\varphi^{\prime} X_{c t}+\delta_{i}+\lambda_{c}+\tau_{t}+\varepsilon_{i c t},
\end{aligned}
$$

where $\ln E_{i c t}$ is $\log$ quarterly employment in industry $i$ in county $c$ in quarter $t$; Treat $_{i}$ is equal to one if industry $i$ is beer, wine, $\&$ liquor retail stores (NAICS=4453); Pass $_{c}$ is equal to one if county $c$ passed the referendum on Sunday sales of alcohol between 2011Q4 (the earliest possible quarter) and 2013Q4 (the end our data) ${ }^{6}$ and Post $_{c t}$ is set equal to one in the first effective quarter $t$ of the referendum in county $c$ and every quarter thereafter. For counties that did not remove sales restrictions, Post $t_{c t}$ is set equal to one in 2011Q4 (and thereafter); this is the first possible date for Sunday sales to be effective in any county. This post-period designation for control counties in the case of varying effective, or treatment, dates follows the standard

\footnotetext{
${ }^{4}$ For reasons mentioned above, NAICS industries 4451 (grocery stores), 4452 (specialty food stores), 4471 (gasoline stations), 4529 (other general merchandise stores), 1029 and 9999 (not otherwise classified) are excluded from all analyses.

${ }^{5}$ There are 6 counties that passed and 7 counties that did not pass the referendum with observations only in either the pre or post period. These observations are included in the analysis, but will not contribute to identification across the pre/post dimension.

${ }^{6}$ By January 2014, only one city (Vidalia) in Toombs County has an effective date after 2013Q4 (2014Q1), and we assign Toombs County as a control county by using our determination rule.
} 
practice for difference analyses in which the post-treatment time period varies by observation (for example, see Ballou and Bhatt 2013).

The time trend, $t$, is fully interacted with all of the triple-difference indicators in order to, primarily, control for differences in employment trends across treated and non-treated industries and across counties that passed and did not pass the referendum. Interacting the trend variable with the post indicator (and all of its interactions) also allows us to capture the effect removing alcohol sales might have had on employment trends, in addition to the potential shift in employment levels captured by Treat $_{i}$ Pass $_{C}$ Post $_{c t}$ (see Galster et al. 2004 and Hotchkiss et al. 2015). Additionally, we constrain the analysis to include, at most, two year's of pre-treatment observations for each industry, in order to balance with the post-treatment time period and to avoid including any of the Great Recession period in our analysis.

Additional county characteristics, $X_{c t}$, in time $t$ might help explain the county's demand for alcohol, thus employment, in beer, wine, \& liquor stores. These characteristics include the race and age composition in the county, population density, as well as the unemployment and labor force participation rates. ${ }^{7}$ County $\left(\lambda_{c}\right)$ and industry $\left(\delta_{i}\right)$ fixed effects, as well as a time trend $\left(\tau_{t}\right)$ are also included, and the standard errors are clustered at the industry level. The importance of accounting for correlation across industries in the standard errors and controlling for time- and unit-specific fixed effects are highlighted in Bertrand et al. (2004), Dachis et al. (2011), and illustrated in Hotchkiss et al. (2015). ${ }^{8}$

County population is used to weight the analysis. This is done to account for different total employment levels across counties, allowing a one percent increase in employment from a large county to contribute more to the estimate of total employment impact than a one percent

\footnotetext{
${ }^{7}$ County demographics were obtained from U.S. Census Population Division, Intercensal Population Estimates, (http://www.census.gov/popest/data/intercensal/).

${ }^{8}$ Also see Bertrand et al. (2004) and Cameron and Miller (2015).
} 
increase in employment from a small county. By not weighting, a one percent change in employment in small counties is inappropriately given the same importance for job creation as a one percent change in employment in large counties.

The fundamental assumption/requirement for validity of any difference-in-differences (or triple-difference) analysis is that the treatment and control groups have the same trend in the outcome variable prior to treatment (Angrist and Pischke 2008; Ch. 5). In our case, this means that pre-treatment trends in employment and hours in the beer, wine, \& liquor store industry should be similar to those in other industries, and that pre-treatment trends in counties removing sales restrictions should be similar to those in counties not removing restrictions. If they are not, then employment in the beer, wine, \& liquor store industry, for example, may simply be on a steeper trajectory than control industries, resulting in a greater mean difference from before to after, relative to the mean difference of the control (which is on a flatter trajectory). We rely on the trend interactions in order to capture differences in trends across treated industry status and across counties based on whether they did or did not remove Sunday sales restrictions.

\section{Results}

\section{A. DDD Regression Results for Employment}

Table 2 contains the results from estimating equation (1) with its full set of county characteristics, county and industry fixed effects, along with a time trend (as a fixed effect) and all of its interactions. One advantage to the specification in equation (1) is that it allows for the calculation of a combined level and trend effect on post-referendum total employment in the treated industry in counties that removed alcohol sales restrictions through the following partial derivative: 
$\frac{\partial \ln E}{\partial(\text { Treat } \times \text { Pass } \times \text { Post })}=\left[\hat{\gamma}_{4}+\hat{\theta}_{7} t\right]$.

This marginal effect tells us the total difference in percentage change in employment between treated and control industries from before to after the referendum dates in counties that removed sales restrictions, relative to the percentage change in employment between treated and control industries in counties that did not remove restrictions; it is reported at the bottom of Table 2 in order to provide a meaningful translation for the parameter estimates. The derivative is calculated for each observation post-referendum ( $t$ greater than or equal to the county's effective date). This average partial derivative can also be translated into the average number of jobs per county by multiplying it by employment prior to the referendum effectiveness date.

\section{[Table 2 about here]}

The first two columns of the table report the double-difference results within treated and control industries, across counties. These results tell us how employment is different before and after the referendums in counties that did and did not remove sales restrictions, separately for liquor stores and the rest of non-retail industries. The marginal effects indicate that there is no statistically significant difference in employment within either the treated or control industries across counties passing and not passing referendums before and after the passage dates.

Column (3) reports the triple-difference results including all counties regardless of what year their referendum was passed. These results tell us that in addition to no statistically significant employment difference within treated and control industries, across pass/nopass counties and referendum dates, there is also no statistical difference in this employment change across counties that did and did not pass a referendum. Overall, there appears to have been no impact from the removal of Sunday alcohol sales on employment in the beer, wine, \& liquor 
store retail industries in those counties passing a referendum, relative to other non-retail industries in counties not passing a referendum.

Columns (4) through (6) in Table 2 report the triple-difference result for a subset of treated counties, based on the year in which they passed their referendum. These analyses include all counties that did not pass a referendum. Restricting the analysis only to counties that held referendums in 2011 or 2012 results in a significant, positive employment impact of removing sales restrictions of 21 percent and six percent, respectively. It may very well be that a longer post time period than is available for those removing restrictions in 2013 is necessary to capture significant employment effects.

To some extent, the lack of significant overall impact of removing alcohol sales restrictions on employment is not surprising. Increasing the workforce on the extensive margin (employment levels) in response to keeping a business open an additional day of the week would be a rather dramatic outcome in such a small industry. However, employers have another tool with which to accommodate additional sales -- that is, increasing the hours of work of their existing workforce (adjustments along the intensive margin). This is the question we turn to now -- whether there is any evidence that average weekly hours for these liquor store workers in counties that passed the referendum increased significantly, relative to other industries, and relative to counties not passing the referendum.

\section{B. DDD Analysis of Weekly Earnings}

Note that if consumers are merely shifting purchases across days of the week within counties that removed restrictions, liquor store operators can meet the new demand of one extra day of sales per week by simply increasing weekly hours of their existing workforce.

Unfortunately, employers are not required to report to the state the average weekly hours of their 
workers, but they do report total quarterly earning from which we construct average weekly earnings by diving by the total number of workers and then by 13 (the number of weeks in a quarter); this is how the BLS constructs their estimate of average weekly earning by industry that they report in the QCEW. There is no reason to believe that the hourly pay of sales clerks or stockers in the beer, wine, \& liquor store industry would rise out of step with wages in other industries, especially since there is likely ample supply of workers with the skills necessary for this type of work. ${ }^{9}$ Assuming hourly wages did not rise for some reason for workers in the treated industry in counties that passed the referendum, if employers increased average hours of their workers in order to meet the new demand by consumers to purchase alcohol on Sundays, then we should see a rise in average weekly earnings among workers in the beer, wine, \& liquor store industry in counties that removed sales restrictions, and no change in counties that did not remove restrictions. The triple-difference analysis performed for log employment is repeated for real (\$R2013Q4) average log weekly earnings; the results are reported in Table 3.

[Table 3 about here]

As with the log employment analysis, not much of the additional county characteristics contribute explanatory power for average log average weekly earnings. This, again, is not surprising given the county, industry, and time fixed effects that are also included. Going straight to the marginal effects at the bottom of the table, like employment, there is no significant difference within treated and control industries across counties that did and did not pass a referendum (these are the DD results in columns 1 and 2). However, average weekly earnings in the treated industry is 2.5 percent higher post-referendum than pre-referendum in counties that

\footnotetext{
${ }^{9}$ In addition, there is evidence that hourly wages were not rising for anyone coming out of the Great Recession (see Rios-Avila and Hotchkiss 2014)
} 
passed a referendum, compared to counties that did not pass the referendum, relative to the same comparison for employment in all other non-retail industries.

The significance of this triple-difference marginal effect, in light of the insignificant double-different result, indicates that there was a greater relative increase in weekly earnings across treated and control industries, than across treated and control counties. In addition, the results in columns (4) through (6), which contain the triple-difference estimates for subsets of treated counties based on the year they passed their referendums, indicate that the positive weekly earnings impact is being driven by observations in counties that passed their referendums in 2011 and 2012. But, unlike the employment results, the overall wage impact (including all counties, regardless of passage year) is statistically significant. Given that the average weekly hours among all employees in Retail Trade in 2011 was about 32 hours per week, a 2.5 percent increase in average weekly earning means workers in beer, wine, \& liquor stores added just under one hour to their average work week (on average, across counties of all sizes). ${ }^{10}$

\section{Falsification Tests and Robustness}

If we are to believe that the positive weekly earnings results above are directly related to the passage by counties of referendums removing restrictions on alcohol sales, then we should see no impact on the rest of retail over this time period, relative to other non-retail industries, since the rest of retail, although similar in nature to the business of beer, wine, \& liquor store retail, should not have been affected by the removal of Sunday sales restrictions.

Table 4 contains the results from the falsification regression analyses. The table contains the marginal effect from the full triple-difference regression where all (non-liquor store) retail and sub categories of retail serve as the false-treated industry while all other non-retail remains

\footnotetext{
${ }^{10}$ Average weekly hours for retail workers was obtained from the St. Louis Fed's FRED database, https://research.stlouisfed.org/fred2/series/AWHAERT.
} 
as the consistent control. We only investigate the log earnings effect since the employment impact was insignificant. If we want to be able to conclude that there is something special going on in the beer, wine, \& liquor store industry over this time period when counties were removing alcohol sales restrictions, we would expect to see all triple-difference marginal effects for the false treated groups in this table to be insignificant.

\section{[Table 4 about here]}

Unfortunately, we do see that weekly earnings of workers in other retail industries (combined and separately in auto and personal care) did change significantly over this time period relative to other non-retail industries, in counties that removed sales restrictions compared to counties that did not. However, the direction of that change was opposite of what was seen in the beer, wine, and liquor store retail industry. The bottom line is that something special happened to the beer, wine, and liquor store industry over the period of time that counties were removing alcohol sales restrictions that resulted in an increase in weekly earnings (read "hours"), relative to other non-retail industries, that was quite distinct from changes going on in the rest of retail. Regarding the "all else equal" assumption as it relates our non-retail control industries, if statistical significance of the results in Table 4 derives from violation of this assumption, then the positive triple difference results reported in Tables 2 and 3 would be underestimates of the true effect of the removal of Sunday alcohol sales.

We also re-estimated the triple-difference earnings equation but changed the classification scheme for counties to be considered treated or not. In one version, we considered a county to have passed a referendum only if all entities (all cities and unincorporated county) in that county removed sales restrictions. Additionally, we considered a county to have passed a referendum if any entity removed sales restrictions. Both of these alternative classifications 
produced similar but quantitatively larger estimates for the impact of removing sales restrictions on earnings (marginal effects of 0.10 and 0.15 , respectively), however we believe these classification schemes are not realistic.

\section{$\underline{\text { V. Conclusions and Implications }}$}

Restricting liquor stores from selling alcohol on Sundays is a hold-over from Prohibition. By the end of 2011, Georgia was only one of three states with these so-called "blue laws" still on the books. After the state legislature voted in 2011 to allow local jurisdictions to decide their own moral and economic fate by allowing alcohol to be sold on Sundays, about one-third of counties and municipalities in Georgia eventually did so by the end of 2013. The analysis in this paper exploits the natural experiment of differential timing across counties of referendums deciding the matter by structuring a triple-difference analysis to determine whether those counties that removed Sunday sales restrictions experienced a boost in employment or average weekly hours in the industry most affected -- beer, wine, \& liquor retail stores -- relative to counties that did not remove the restrictions.

Controlling for county and industry fixed effects and time trends, the triple-difference analysis did not reveal any significant impact on employment, but did point to a 2.5 percent rise in weekly earnings in the beer, wine \& liquor store industry, post-referendum, relative to other non-retail industries, in counties that removed alcohol sales restrictions, relative to counties that did not; we estimate this translates into just under one additional hour of work per week, on average for those workers. Together, these employment and earnings results suggest that beer, wine, \& liquor store employers responded to increased demand on Sundays by adjusting their workforce along the intensive margin, rather than by increasing their workforce. 
Falsification tests support the conclusion that something special happened in the beer, wine, \& liquor store industry over the period of time counties were removing alcohol sales restrictions quite distinct from labor market changes going on in other retail industries.

The finding of increased hours among workers in the beer, wine, \& liquor retail store industry is consistent with either an increase in consumption as a result of allowing alcohol sales on Sunday, or, as suggested by Carpenter and Eisenberg (2009), merely a shift in consumption. However, the results suggest that liquor store owners did not respond to allowing sales on Sunday by merely shifting the day of the week on which they are closed -- it appears that they responded by increasing their hours of operation and expanded the hours of their workforce to do so. 


\section{References}

AP Reports. "UPDATE: Georgia Senate Approves Sunday Alcohol Sales Proposal; McKoon votes 'no'." Ledger-Inquirer (16 March 2011), http://www.ledgerenquirer.com/2011/03/16/1500575/georgia-senate-approves-sunday.html (accessed 01 May 2013).

Angrist, Joshua and Jorn-Steffen Pischke. "Mostly Harmless Econometrics: An Empiricist's Companion” Princeton, NJ: Princeton University Press. 2008.

Bellou, Andriana and Rachana Bhatt. "Reducing Underage Alcohol and Tobacco Use: Evidence from the Introduction of Vertical Identification Cards." Journal of Health Economics 32 (2013): 353-66.

Bertrand, Marianne; Esther Duflo; and Sendhil Mullainathan. "How Much Should We Trust Differences-in-Differences Estimates?" Quarterly Economics Journal 119(1) (2004): $249-75$.

Bonner, Jeanne. "Georgia Considers Lifting Ban on Sunday Alcohol Sales." Marketplace Economy (29 March 2011), http://www.marketplace.org/topics/economy/georgiaconsiders-lifting-ban-sunday-alcohol-sales (accessed 01 May 2013).

Cameron A. Colin and Douglas L. Miller. "A Practitioner's Guide to Cluster-robust Inference." Journal of Human Resources (forthcoming, Spring 2015).

Carpenter, Christopher S. and Daniel Eisenberg. "Effects of Sunday Sales Restrictions on Overall and Day-specific Alcohol Consumption: Evidence from Canada." Journal of Studies on Alcohol and Drugs (January 2009): 126-33.

Committee on Ways and Means, House of Representatives. 2004. "Greenbook". WMCP 108-6, Section 4. Accessed March 2004. Available at http://waysandmeans.house.gov/media/pdf/greenbook2003/108transmittal.pdf

Dachis, Ben; Gilles Duranton; and Matthew A. Turner. "The Effects of Land Transfer Taxes on Real Estate Markets: Evidence from a Natural Experiment in Toronto." Journal of Economic Geography 12(2) (2011): 327-54.

Galster, George; Peter Tatian; and Kathryn Pettit. "Supportive Housing and Neighborhood Property Value Externalities. Land Economics 80(1) (2004): 33-54.

Gruber, Jonathan. "The Church Versus the Mall: What Happens When Religion Faces Increased Secular Competition?" The Quarterly Journal of Economics 123(2) (2008):831-862.

Guntzel, Jeff Severns. "Sunday liquor sales: Who is fighting them and why? Minnpost (3 March 2011). https://www.minnpost.com/intelligencer/2011/03/sunday-liquor-sales-whofighting-them-and-why (accessed 20 February 2015). 
Hotchkiss, Julie L.; Robert E. Moore; and Fernando Rios-Avila. "Reevaluation of the Employment Impact of the 1996 Summer Olympic Games." Southern Economic Journal 81(3) (January 2015): 619-32.

Jenkins, Ben. "Pro \& Con: Should Georgia Allow Retail Alcohol Sales on Sundays?" AJC.com (14 February 2014), http://www.ajc.com/news/news/opinion/pro-con-should-georgiaallow-retail-alcohol-sales-/nQqfQ/ (accessed 01 May 2013).

Rios-Avila, Fernando and Julie L. Hotchkiss. "A Decade of Flat Wages?" Levy Institute Policy Note (2014/4).

Weir, William. "Sunday Sales have Risks." Courant.com (02 March 2012), http://articles.courant.com/2012-03-02/health/hc-cdc-liquor-sales-030220120301_1_alcohol-sales-sales-ban-liquor-sales (accessed 01 May 2013). 
Table 1. Sample means

\begin{tabular}{|c|c|c|c|c|c|c|c|c|}
\hline \multirow{5}{*}{ Variable } & \multicolumn{4}{|c|}{ Beer, Wine, \& Liquor Retail Stores (Naics=4453) } & \multicolumn{4}{|c|}{ All Other Industries, Excluding Retail } \\
\hline & \multicolumn{2}{|c|}{$\begin{array}{c}\text { County Removed } \\
\text { Restrictions }\end{array}$} & \multicolumn{2}{|c|}{$\begin{array}{c}\text { County Did Not } \\
\text { Remove Restrictions } \\
\end{array}$} & \multicolumn{2}{|c|}{$\begin{array}{c}\text { County Removed } \\
\text { Restrictions } \\
\end{array}$} & \multicolumn{2}{|c|}{$\begin{array}{c}\text { County Did Not } \\
\text { Remove Restrictions }\end{array}$} \\
\hline & Before & After & Before & After & Before & After & Before & After \\
\hline & Restriction & Restriction & Restriction & Restriction & Restriction & Restriction & Restriction & Restriction \\
\hline & Removal & Removal & Removal & Removal & Removal & Removal & Removal & Removal \\
\hline \multirow[t]{2}{*}{ Quarterly Employment Level } & 505.54 & 551.14 & 68.12 & 64.83 & 2650.84 & 2890.20 & 240.08 & 245.68 \\
\hline & $(522.00)$ & $(574.45)$ & $(129.51)$ & $(110.34)$ & $(7857.48)$ & $(8936.74)$ & $(733.83)$ & $(761.25)$ \\
\hline \multirow[t]{2}{*}{ Average Weekly Earnings (\$) } & 142.86 & 138.30 & 148.22 & 121.59 & 323.88 & 325.17 & 226.79 & 229.76 \\
\hline & $(35.1752)$ & $(35.3544)$ & $(78.41)$ & $(51.12)$ & $(332.8922)$ & $(243.20)$ & $(181.47)$ & $(190.88)$ \\
\hline \multirow[t]{2}{*}{ Percent population that is black } & .3301 & .3291 & .2714 & .2777 & .3363 & .3376 & .2527 & .2517 \\
\hline & $(.1676)$ & $(.1669)$ & $(.1892)$ & $(.1858)$ & $(.164)$ & $(.1626)$ & $(.1923)$ & $(.1904)$ \\
\hline \multirow[t]{2}{*}{ Percent of pop that is not white or black } & .0672 & .0709 & .0284 & .031 & .0705 & .0744 & .0279 & .0305 \\
\hline & $(.0323)$ & $(.0328)$ & $(.0134)$ & $(.0138)$ & $(.0328)$ & $(.0331)$ & $(.0124)$ & $(.0128)$ \\
\hline \multirow[t]{2}{*}{ Percent of population that is Hispanic } & .1002 & .1026 & .0552 & .0595 & .1032 & .1048 & .0529 & .0562 \\
\hline & $(.06)$ & $(.0633)$ & $(.0392)$ & $(.0404)$ & $(.0594)$ & $(.0623)$ & $(.0388)$ & $(.0397)$ \\
\hline \multirow[t]{2}{*}{ Percent of population between ages 20-54 } & .5029 & .4972 & .4648 & .4618 & .5061 & .5006 & .4661 & .4616 \\
\hline & $(.0293)$ & $(.0288)$ & $(.0291)$ & $(.0306)$ & $(.0282)$ & $(.0276)$ & $(.0324)$ & $(.0346)$ \\
\hline \multirow[t]{2}{*}{ Percent of population aged 55 and over } & .2105 & .2212 & .2514 & .2634 & .2078 & .2183 & .251 & .2645 \\
\hline & $(.0333)$ & $(.0324)$ & $(.0523)$ & $(.0523)$ & $(.0307)$ & $(.0298)$ & $(.0558)$ & $(.0572)$ \\
\hline \multirow[t]{2}{*}{ Population density (people per sq mile) } & 1171.367 & 1208.432 & 136.4719 & 138.0517 & 1277.231 & 1319.521 & 137.3692 & 139.4384 \\
\hline & $(839.9501)$ & $(850.6487)$ & $(130.4013)$ & (135.4107) & $(832.7869)$ & $(842.387)$ & $(126.2335)$ & $(129.4011)$ \\
\hline \multirow[t]{2}{*}{ Unemployment rate $(\%)$} & 9.8087 & 8.3568 & 11.0568 & 9.6212 & 9.7546 & 8.3248 & 10.9179 & 9.3899 \\
\hline & $(1.3988)$ & $(1.2911)$ & $(2.0897)$ & $(1.8369)$ & $(1.3024)$ & $(1.2312)$ & $(2.0815)$ & $(1.9535)$ \\
\hline \multirow[t]{2}{*}{ Labor force participation rate $(\%)$} & .6292 & .6197 & .5734 & .5615 & .6332 & .6223 & .5791 & .5692 \\
\hline & $(.0493)$ & $(.0454)$ & $(.0692)$ & $(.0669)$ & $(.0458)$ & $(.0427)$ & $(.0743)$ & $(.0739)$ \\
\hline N (total) & 481 & 334 & 461 & 443 & 82818 & 59300 & 71705 & 70470 \\
\hline Number of counties & 57 & 56 & 55 & 54 & 65 & 65 & 94 & 94 \\
\hline
\end{tabular}


Note: Means are weighted by county population, standard deviation are in parenthesis. The after restriction removal period ranges from $2011 \mathrm{Q} 4$ to 2013Q4. The first year of observation for any county is 2009Q3. Number of observation reflects the number of industries, number of counties, and number of quarters across which the means are calculated. 
Table 2. Triple- and double-difference estimation results for average log employment.

\begin{tabular}{|c|c|c|c|c|c|c|}
\hline \multirow[b]{3}{*}{ VARIABLES } & \multicolumn{2}{|c|}{ Double-difference Estimation } & \multicolumn{4}{|c|}{ Triple-difference Estimation } \\
\hline & $(1)$ & $(2)$ & $(3)$ & $(4)$ & $(5)$ & (6) \\
\hline & $\begin{array}{l}\text { Treated } \\
\text { industry }\end{array}$ & $\begin{array}{l}\text { Control } \\
\text { industry }\end{array}$ & $\begin{array}{l}\text { All years of } \\
\text { treated counties }\end{array}$ & $\begin{array}{l}2011 \text { treated } \\
\text { counties only }\end{array}$ & $\begin{array}{l}2012 \text { treated } \\
\text { counties only }\end{array}$ & $\begin{array}{l}2013 \text { treated } \\
\text { counties only }\end{array}$ \\
\hline $\begin{array}{l}\text { Treat }_{i}=1 \\
\text { (industry NAICS=4453) }\end{array}$ & & & $\begin{array}{c}1.4165 * * * \\
(0.0455)\end{array}$ & $\begin{array}{c}0.8146 * * * \\
(0.0360)\end{array}$ & $\begin{array}{c}1.4790 * * * \\
(0.0425)\end{array}$ & $\begin{array}{c}0.4315 * * * \\
(0.0285)\end{array}$ \\
\hline $\begin{array}{l}\operatorname{Pass}_{c}=1 \\
\text { (county removed Sunday sales restrictions) }\end{array}$ & $\begin{array}{c}0.7726 \\
(1.3324)\end{array}$ & $\begin{array}{c}-0.7758 * * * \\
(0.1803)\end{array}$ & $\begin{array}{c}-0.7581 * * \\
(0.3572)\end{array}$ & $\begin{array}{c}0.2778 \\
(0.6783)\end{array}$ & $\begin{array}{l}0.5125^{*} \\
(0.2663)\end{array}$ & $\begin{array}{l}-0.4878 \\
(0.3819)\end{array}$ \\
\hline Post $_{c t}=1$ & $0.4414^{*}$ & -0.0065 & -0.0058 & 0.0973 & -0.0764 & -0.1626 \\
\hline $\begin{array}{l}\text { (qtr is effective date or later for county) } \\
\text { Treat }_{i} \operatorname{Pass}_{c}\end{array}$ & $(0.2492)$ & $(0.0311)$ & $\begin{array}{c}(0.0485) \\
0.1679 * * \\
(0.0818)\end{array}$ & $\begin{array}{c}(0.1210) \\
0.2045 * * * \\
(0.0571)\end{array}$ & $\begin{array}{c}(0.0842) \\
0.2004 * * \\
(0.0907)\end{array}$ & $\begin{array}{l}(0.1502) \\
-0.2348^{*} \\
(0.1339)\end{array}$ \\
\hline Treat $_{i}$ Post $_{c t}$ & & & $\begin{array}{c}0.3568 * * * \\
(0.0291)\end{array}$ & $\begin{array}{c}0.3705 * * * \\
(0.0254)\end{array}$ & $\begin{array}{l}0.3569 * * * \\
(0.0292)\end{array}$ & $\begin{array}{l}0.3721 * * * \\
(0.0254)\end{array}$ \\
\hline Pass $_{c}$ Post $_{c t}$ & $\begin{array}{l}-0.3424 \\
(0.2624)\end{array}$ & $\begin{array}{l}-0.0274 \\
(0.0283)\end{array}$ & $\begin{array}{l}-0.0276 \\
(0.0388)\end{array}$ & $\begin{array}{l}-0.0644 \\
(0.0460)\end{array}$ & $\begin{array}{l}-0.0338 \\
(0.0513)\end{array}$ & $\begin{array}{c}0.1991 \\
(0.2428)\end{array}$ \\
\hline Treat $_{i}$ Pass $_{c}$ Post $_{c t}$ & & & $\begin{array}{c}-0.4375 * * * \\
(0.0443)\end{array}$ & $\begin{array}{c}-0.4680 * * * \\
(0.0487)\end{array}$ & $\begin{array}{c}-0.3690 * * * \\
(0.0547)\end{array}$ & $\begin{array}{l}-0.7488^{*} \\
(0.4099)\end{array}$ \\
\hline$t \times$ Treat $_{i}$ & & & $\begin{array}{c}0.0259 * * * \\
(0.0022)\end{array}$ & $\begin{array}{c}0.0263 * * * \\
(0.0019)\end{array}$ & $\begin{array}{c}0.0259 * * * \\
(0.0022)\end{array}$ & $\begin{array}{c}0.0268 * * * \\
(0.0018)\end{array}$ \\
\hline$t \times \operatorname{Pass}_{C}$ & $\begin{array}{l}-0.0280 \\
(0.0179)\end{array}$ & $\begin{array}{c}0.0013 \\
(0.0017)\end{array}$ & $\begin{array}{c}0.0012 \\
(0.0031)\end{array}$ & $\begin{array}{l}-0.0060^{*} \\
(0.0033)\end{array}$ & $\begin{array}{c}0.0017 \\
(0.0038)\end{array}$ & $\begin{array}{c}0.0166 \\
(0.0151)\end{array}$ \\
\hline$t \times$ Post $_{c t}$ & $\begin{array}{l}-0.0440 * \\
(0.0235)\end{array}$ & $\begin{array}{c}0.0003 \\
(0.0031)\end{array}$ & $\begin{array}{c}0.0002 \\
(0.0048)\end{array}$ & $\begin{array}{l}-0.0070 \\
(0.0066)\end{array}$ & $\begin{array}{c}0.0074 \\
(0.0083)\end{array}$ & $\begin{array}{c}0.0161 \\
(0.0162)\end{array}$ \\
\hline tx $\times$ Treat $_{i}$ Pass $_{C}$ & & & $\begin{array}{c}-0.0143 * * * \\
(0.0034)\end{array}$ & $\begin{array}{c}-0.0407 * * * \\
(0.0032)\end{array}$ & $\begin{array}{c}-0.0167 * * * \\
(0.0036)\end{array}$ & $\begin{array}{l}0.0173^{*} \\
(0.0091)\end{array}$ \\
\hline t× Treat $_{i}$ Post $_{c t}$ & & & $\begin{array}{c}-0.0331 * * * \\
(0.0029)\end{array}$ & $\begin{array}{c}-0.0343 * * * \\
(0.0025)\end{array}$ & $\begin{array}{c}-0.0331 * * * \\
(0.0029)\end{array}$ & $\begin{array}{c}-0.0346^{* * *} \\
(0.0025)\end{array}$ \\
\hline$t \times \operatorname{Pass}_{c}$ Post $_{c t}$ & $\begin{array}{c}0.0341 \\
(0.0222)\end{array}$ & $\begin{array}{c}0.0030 \\
(0.0027)\end{array}$ & $\begin{array}{c}0.0030 \\
(0.0039)\end{array}$ & $\begin{array}{l}0.0087^{*} \\
(0.0046)\end{array}$ & $\begin{array}{c}0.0023 \\
(0.0049)\end{array}$ & $\begin{array}{l}-0.0184 \\
(0.0193)\end{array}$ \\
\hline$t \times$ Treat $_{i}$ Pass $_{c}$ Post $_{c t}$ & & & $\begin{array}{c}0.0315 * * * \\
(0.0040)\end{array}$ & $\begin{array}{c}0.0485 * * * \\
(0.0048)\end{array}$ & $\begin{array}{c}0.0289 * * * \\
(0.0044)\end{array}$ & $\begin{array}{c}0.0454 * * \\
(0.0202)\end{array}$ \\
\hline
\end{tabular}




\begin{tabular}{|c|c|c|c|c|c|c|}
\hline \multirow[b]{3}{*}{ VARIABLES } & \multicolumn{2}{|c|}{ Double-difference Estimation } & \multicolumn{4}{|c|}{ Triple-difference Estimation } \\
\hline & $(1)$ & $(2)$ & $(3)$ & $(4)$ & $(5)$ & $(6)$ \\
\hline & $\begin{array}{l}\text { Treated } \\
\text { industry }\end{array}$ & $\begin{array}{l}\text { Control } \\
\text { industry }\end{array}$ & $\begin{array}{l}\text { All years of } \\
\text { treated counties }\end{array}$ & $\begin{array}{l}2011 \text { treated } \\
\text { counties only }\end{array}$ & $\begin{array}{l}2012 \text { treated } \\
\text { counties only }\end{array}$ & $\begin{array}{l}2013 \text { treated } \\
\text { counties only }\end{array}$ \\
\hline \multirow[t]{2}{*}{ Percent population that is black } & -0.1095 & -0.7047 & -0.7135 & -1.2557 & -0.1210 & -0.9501 \\
\hline & $(4.1671)$ & $(0.6378)$ & $(1.2968)$ & $(1.3220)$ & $(1.3528)$ & $(1.2494)$ \\
\hline \multirow[t]{2}{*}{ Percent of pop that is not white or black } & 3.7236 & -3.8281 & -3.7750 & -7.1414 & -2.4825 & -2.5208 \\
\hline & $(9.4436)$ & $(2.4984)$ & $(3.4453)$ & $(5.3115)$ & $(3.5790)$ & $(5.5418)$ \\
\hline \multirow[t]{2}{*}{ Percent of population that is Hispanic } & -2.3469 & -1.0529 & -1.0648 & -1.3354 & -2.5777 & -0.5753 \\
\hline & $(10.9232)$ & $(1.3268)$ & $(2.3694)$ & $(2.6219)$ & $(2.7469)$ & $(2.5311)$ \\
\hline \multirow[t]{2}{*}{ Percent of population between ages $20-54$} & -1.9438 & -0.0473 & -0.0601 & 0.1601 & 0.4950 & -0.7429 \\
\hline & $(7.9730)$ & $(1.1605)$ & $(1.4096)$ & $(1.4314)$ & $(1.5272)$ & $(1.1516)$ \\
\hline \multirow[t]{2}{*}{ Percent of population ages 55 and over } & 3.4893 & $2.6288 * *$ & $2.6545^{*}$ & 1.8085 & 1.9012 & 0.9271 \\
\hline & $(7.1367)$ & $(1.1998)$ & $(1.5023)$ & $(1.9437)$ & $(1.6093)$ & $(1.5158)$ \\
\hline \multirow[t]{2}{*}{ Population density (people per sq mile) } & 0.0010 & -0.0001 & -0.0001 & $0.0053 * * *$ & -0.0000 & $0.0066^{* *}$ \\
\hline & $(0.0008)$ & $(0.0001)$ & $(0.0003)$ & $(0.0015)$ & $(0.0003)$ & $(0.0030)$ \\
\hline \multirow[t]{2}{*}{ Unemployment rate $(\%)$} & 0.0026 & $-0.0129 * * *$ & $-0.0127 * *$ & $-0.0102 * *$ & $-0.0105^{*}$ & $-0.0095 * *$ \\
\hline & $(0.0255)$ & $(0.0034)$ & $(0.0053)$ & $(0.0052)$ & $(0.0062)$ & $(0.0048)$ \\
\hline \multirow[t]{2}{*}{ Labor force participation rate $(\%)$} & 1.2071 & -0.0863 & -0.0710 & 0.4249 & 0.1664 & 0.4275 \\
\hline & $(1.6425)$ & $(0.2015)$ & $(0.2645)$ & $(0.2960)$ & $(0.2879)$ & $(0.2667)$ \\
\hline \multirow[t]{2}{*}{ Constant } & 2.1940 & 1.4631 & 1.4490 & 1.6801 & 1.1563 & $2.4217^{* *}$ \\
\hline & $(4.8145)$ & $(0.8886)$ & $(1.0512)$ & $(1.2918)$ & $(1.1186)$ & $(0.9596)$ \\
\hline Observations & 1,719 & 284,261 & 285,980 & 183,278 & 231,652 & 157,240 \\
\hline R-squared & 0.9781 & 0.6679 & 0.6684 & 0.5431 & 0.6877 & 0.5112 \\
\hline$\partial \ln E / \partial($ Treat $\times$ Post $)$ & $\begin{array}{c}0.162 \\
(0.141)\end{array}$ & $\begin{array}{c}0.0164 \\
(0.0174)\end{array}$ & & & & \\
\hline$\partial \ln E / \partial($ Treat $\times$ Pass $\times$ Post $)$ & & & $\begin{array}{c}0.0242 \\
(00290)\end{array}$ & $0.209 * * *$ & $0.0637 * *$ & $\begin{array}{c}0.0215 \\
(00812)\end{array}$ \\
\hline
\end{tabular}

Notes: Dependent variable is $\log$ quarterly employment in industry $i$, county $c$, quarter $t$. Regression also includes industry, county, and quarter fixed effects. Observations are weighted by total county population. All non-retail industries serve as the control. *,**,***=> statistically different from zero at the 90, 95, and 99 percent confidence levels. Standard errors are clustered at the industry level. 
Table 3. Triple- and double-difference estimation results for average weekly earnings.

\begin{tabular}{|c|c|c|c|c|c|c|}
\hline \multirow[b]{2}{*}{ VARIABLES } & \multicolumn{2}{|c|}{ Double-difference Estimation } & \multicolumn{4}{|c|}{ Triple-difference Estimation } \\
\hline & $\begin{array}{c}\text { (1) } \\
\text { Treated } \\
\text { industry }\end{array}$ & $\begin{array}{c}(2) \\
\text { Control } \\
\text { industry } \\
\end{array}$ & $\begin{array}{c}(3) \\
\text { All years of } \\
\text { treated counties }\end{array}$ & $\begin{array}{c}\text { (4) } \\
2011 \text { treated } \\
\text { counties only }\end{array}$ & $\begin{array}{c}(5) \\
2012 \text { treated } \\
\text { counties only }\end{array}$ & $\begin{array}{c}(6) \\
2013 \text { treated } \\
\text { counties only }\end{array}$ \\
\hline $\begin{array}{l}\text { Treat }_{i}=1 \\
\text { (industry NAICS=4453) }\end{array}$ & & & $\begin{array}{c}0.1017 * * * \\
(0.0111)\end{array}$ & $\begin{array}{c}0.2487 * * * \\
(0.0109)\end{array}$ & $\begin{array}{c}-0.1457 * * * \\
(0.0114)\end{array}$ & $\begin{array}{c}-0.2040 * * * \\
(0.0110)\end{array}$ \\
\hline $\begin{array}{l}\operatorname{Pass}_{c}=1 \\
\text { (county removed Sunday sales restrictions) }\end{array}$ & $\begin{array}{l}-1.2814^{*} \\
(0.6605)\end{array}$ & $\begin{array}{l}0.1190^{*} \\
(0.0650)\end{array}$ & $\begin{array}{c}0.1167 \\
(0.1300)\end{array}$ & $\begin{array}{l}0.4874^{*} \\
(0.2900)\end{array}$ & $\begin{array}{c}0.1196 \\
(0.0911)\end{array}$ & $\begin{array}{l}-0.0057 \\
(0.1608)\end{array}$ \\
\hline $\begin{array}{l}\text { Post }_{c t}=1 \\
\text { (qtr is effective date or later for county) }\end{array}$ & $\begin{array}{c}0.0694 \\
(0.1536)\end{array}$ & $\begin{array}{l}0.0368 * * \\
(0.0164)\end{array}$ & $\begin{array}{c}0.0373 \\
(0.0232)\end{array}$ & $\begin{array}{l}-1.1164 * * * \\
(0.1140)\end{array}$ & $\begin{array}{c}0.0461 \\
(0.0424)\end{array}$ & $\begin{array}{c}0.0217 \\
(0.0653)\end{array}$ \\
\hline Treat $_{i}$ Pass $_{c}$ & & & $\begin{array}{c}-0.3289 * * * \\
(0.0153)\end{array}$ & $\begin{array}{l}-0.3068 * * * \\
(0.0129)\end{array}$ & $\begin{array}{c}-0.3052 * * * \\
(0.0176)\end{array}$ & $\begin{array}{c}-0.2845 * * * \\
(0.0384)\end{array}$ \\
\hline Treat $_{i}$ Post $_{c t}$ & & & $\begin{array}{c}0.0342 * * \\
(0.0135)\end{array}$ & $\begin{array}{l}0.0372 * * * \\
(0.0132)\end{array}$ & $\begin{array}{c}0.0335^{* *} \\
(0.0135)\end{array}$ & $\begin{array}{c}0.0383 * * * \\
(0.0131)\end{array}$ \\
\hline Pass $_{c}$ Post $_{c t}$ & $\begin{array}{c}0.0059 \\
(0.1382)\end{array}$ & $\begin{array}{l}-0.0079 \\
(0.0237)\end{array}$ & $\begin{array}{l}-0.0080 \\
(0.0178)\end{array}$ & $\begin{array}{l}-0.0282 \\
(0.0204)\end{array}$ & $\begin{array}{c}0.0040 \\
(0.0249)\end{array}$ & $\begin{array}{c}0.0565 \\
(0.1292)\end{array}$ \\
\hline Treat $_{i}$ Pass $_{c}$ Post $_{c t}$ & & & $\begin{array}{c}-0.1396 * * * \\
(0.0186)\end{array}$ & $\begin{array}{c}-0.1845 * * * \\
(0.0213)\end{array}$ & $\begin{array}{c}-0.1190 * * * \\
(0.0227)\end{array}$ & $\begin{array}{c}-0.8453 * * * \\
(0.1390)\end{array}$ \\
\hline$t \times$ Treat $_{i}$ & & & $\begin{array}{c}-0.0167 * * * \\
(0.0009)\end{array}$ & $\begin{array}{c}-0.0167 * * * \\
(0.0009)\end{array}$ & $\begin{array}{c}-0.0167 * * * \\
(0.0009)\end{array}$ & $\begin{array}{c}-0.0165 * * * \\
(0.0009)\end{array}$ \\
\hline$t \times \operatorname{Pass}_{C}$ & $\begin{array}{c}0.0063 \\
(0.0110)\end{array}$ & $\begin{array}{l}-0.0014 \\
(0.0010)\end{array}$ & $\begin{array}{l}-0.0015 \\
(0.0012)\end{array}$ & $\begin{array}{l}-0.0009 \\
(0.0015)\end{array}$ & $\begin{array}{r}-0.0025^{*} \\
(0.0015)\end{array}$ & $\begin{array}{c}0.0038 \\
(0.0069)\end{array}$ \\
\hline$t \times$ Post $_{c t}$ & $\begin{array}{l}-0.0082 \\
(0.0160)\end{array}$ & $\begin{array}{c}-0.0032 * * \\
(0.0016)\end{array}$ & $\begin{array}{l}-0.0033 \\
(0.0022)\end{array}$ & $\begin{array}{c}0.0681 * * * \\
(0.0064)\end{array}$ & $\begin{array}{l}-0.0043 \\
(0.0040)\end{array}$ & $\begin{array}{c}0.0002 \\
(0.0073)\end{array}$ \\
\hline t×Treat ${ }_{i}$ Pass $_{c}$ & & & $\begin{array}{c}0.0140 * * * \\
(0.0012)\end{array}$ & $\begin{array}{l}-0.0024^{*} \\
(0.0013)\end{array}$ & $\begin{array}{c}0.0119 * * * \\
(0.0013)\end{array}$ & $\begin{array}{c}0.0140 * * * \\
(0.0028)\end{array}$ \\
\hline t× Treat $_{i}$ Post $_{c t}$ & & & $\begin{array}{c}-0.0051 * * * \\
(0.0013)\end{array}$ & $\begin{array}{c}-0.0052 * * * \\
(0.0013)\end{array}$ & $\begin{array}{c}-0.0050 * * * \\
(0.0013)\end{array}$ & $\begin{array}{c}-0.0054 * * * \\
(0.0013)\end{array}$ \\
\hline$t \times \operatorname{Pass}_{c}$ Post $_{c t}$ & $\begin{array}{c}0.0027 \\
(0.0142)\end{array}$ & $\begin{array}{c}0.0009 \\
(0.0017)\end{array}$ & $\begin{array}{c}0.0009 \\
(0.0017)\end{array}$ & $\begin{array}{c}0.0021 \\
(0.0020)\end{array}$ & $\begin{array}{c}0.0005 \\
(0.0022)\end{array}$ & $\begin{array}{l}-0.0048 \\
(0.0092)\end{array}$ \\
\hline t Treat $_{i}$ Pass $_{c}$ Post $_{c t}$ & & & $\begin{array}{c}0.0112 * * * \\
(0.0016)\end{array}$ & $\begin{array}{c}0.0251 * * * \\
(0.0021)\end{array}$ & $\begin{array}{c}0.0113 * * * \\
(0.0019)\end{array}$ & $\begin{array}{c}0.0483 * * * \\
(0.0077)\end{array}$ \\
\hline
\end{tabular}




\begin{tabular}{|c|c|c|c|c|c|c|}
\hline \multirow[b]{3}{*}{ VARIABLES } & \multicolumn{2}{|c|}{ Double-difference Estimation } & \multicolumn{4}{|c|}{ Triple-difference Estimation } \\
\hline & $(1)$ & $(2)$ & (3) & $(4)$ & $(5)$ & (6) \\
\hline & $\begin{array}{l}\text { Treated } \\
\text { industry }\end{array}$ & $\begin{array}{l}\text { Control } \\
\text { industry }\end{array}$ & $\begin{array}{l}\text { All years of } \\
\text { treated counties }\end{array}$ & $\begin{array}{l}2011 \text { treated } \\
\text { counties only }\end{array}$ & $\begin{array}{l}2012 \text { treated } \\
\text { counties only }\end{array}$ & $\begin{array}{l}2013 \text { treated } \\
\text { counties only }\end{array}$ \\
\hline \multirow[t]{2}{*}{ Percent population that is black } & 2.0193 & $-0.5272 *$ & -0.5208 & -0.4265 & -0.6715 & -0.5210 \\
\hline & $(2.2881)$ & $(0.2677)$ & $(0.4578)$ & $(0.5952)$ & $(0.4995)$ & $(0.5514)$ \\
\hline \multirow[t]{2}{*}{ Percent of pop that is not white or black } & -3.3694 & 0.9146 & 0.9075 & 2.2960 & 0.5506 & 2.7099 \\
\hline & $(6.4158)$ & $(0.8932)$ & $(1.3758)$ & $(2.7598)$ & $(1.4235)$ & $(2.2635)$ \\
\hline \multirow[t]{2}{*}{ Percent of population that is Hispanic } & -4.3536 & -0.0299 & -0.0354 & $-2.4799 * *$ & 0.5063 & -1.3970 \\
\hline & $(5.4703)$ & $(0.6948)$ & $(0.9621)$ & $(1.1645)$ & $(1.1119)$ & $(1.0657)$ \\
\hline \multirow[t]{2}{*}{ Percent of population between ages $20-54$} & 0.3783 & -0.2096 & -0.2396 & -0.0523 & -0.5091 & 0.1946 \\
\hline & $(4.6776)$ & $(0.5435)$ & $(0.6524)$ & $(0.7700)$ & $(0.7205)$ & $(0.6534)$ \\
\hline \multirow[t]{2}{*}{ Percent of population ages 55 and over } & 2.7959 & $-1.4338 * *$ & $-1.4238 * *$ & -0.9795 & $-1.6410 * *$ & -0.8071 \\
\hline & $(3.8567)$ & $(0.5834)$ & $(0.7089)$ & $(0.9539)$ & $(0.7443)$ & $(0.7903)$ \\
\hline \multirow[t]{2}{*}{ Population density (people per sq mile) } & 0.0002 & -0.0001 & -0.0001 & 0.0003 & -0.0000 & -0.0000 \\
\hline & $(0.0005)$ & $(0.0001)$ & $(0.0001)$ & $(0.0007)$ & $(0.0001)$ & $(0.0012)$ \\
\hline \multirow[t]{2}{*}{ Unemployment rate $(\%)$} & 0.0211 & -0.0019 & -0.0018 & 0.0012 & -0.0011 & 0.0024 \\
\hline & $(0.0159)$ & $(0.0029)$ & $(0.0022)$ & $(0.0021)$ & $(0.0025)$ & $(0.0020)$ \\
\hline \multirow[t]{2}{*}{ Labor force participation rate $(\%)$} & -0.6606 & -0.1212 & -0.1190 & 0.0139 & -0.1038 & -0.0268 \\
\hline & $(0.8798)$ & $(0.1102)$ & $(0.1284)$ & $(0.1304)$ & $(0.1375)$ & $(0.1296)$ \\
\hline \multirow[t]{2}{*}{ Constant } & 4.2762 & $5.4560 * * *$ & $5.4640 * * *$ & $5.1384 * * *$ & $5.8648 * * *$ & $5.3728 * * *$ \\
\hline & $(2.8712)$ & $(0.4783)$ & $(0.4847)$ & $(0.6560)$ & $(0.5189)$ & $(0.5402)$ \\
\hline Observations & 1,719 & 284,261 & 285,980 & 183,246 & 231,620 & 157,208 \\
\hline R-squared & 0.7907 & 0.5312 & 0.5335 & 0.4358 & 0.5539 & 0.4115 \\
\hline$\partial \ln E / \partial($ Treat $\times$ Post $)$ & $\begin{array}{c}0.0462 \\
(0.0930)\end{array}$ & $\begin{array}{c}0.00494 \\
(0.00826)\end{array}$ & & & & \\
\hline \multirow[t]{2}{*}{$\partial \ln E / \partial($ Treat $\times$ Pass $\times$ Post $)$} & & & $0.0250 * *$ & $0.167 * * *$ & $0.0509 * * *$ & -0.0261 \\
\hline & & & $(0.0107)$ & $(0.0119)$ & $(0.0119)$ & $(0.0238)$ \\
\hline
\end{tabular}

Notes: Dependent variable is $\log$ quarterly employment in industry $i$, county $c$, quarter $t$. Regression also includes industry, county, and quarter fixed effects. Observations are weighted by total county population. All non-retail industries serve as the control. *,**,***=> statistically different from zero at the 90, 95, and 99 percent confidence levels. Standard errors are clustered at the industry level. 
Table 4. Marginal effects estimates from triple-difference estimates for log weekly earnings on false treated industries and for alternative definitions of treated counties.

\begin{tabular}{|c|c|}
\hline & $\begin{array}{c}\text { DDD marginal effect } \\
\partial \ln E / \partial(\text { Treat } \times \text { Pass } \times \text { Post })\end{array}$ \\
\hline True treated industry: Beer, Wine, \& Liquor Stores & $\begin{array}{c}0.0250^{* *} \\
(0.0107)\end{array}$ \\
\hline $\begin{array}{l}\text { False Treated Industries } \\
\text { All other retail (not 4453) }\end{array}$ & $\begin{array}{c}-0.0456^{* *} \\
(0.0208)\end{array}$ \\
\hline Auto retail & $\begin{array}{l}-0.0788 * * * \\
\quad(0.0225)\end{array}$ \\
\hline Furniture \& Building retail & $\begin{array}{l}-0.0412 \\
(0.0268)\end{array}$ \\
\hline Personal Care retail & $\begin{array}{l}-0.0818 * * * \\
\quad(0.0103)\end{array}$ \\
\hline Department store retail & $\begin{array}{c}0.0083 \\
(0.0205)\end{array}$ \\
\hline Miscellaneous retail & $\begin{array}{l}-0.0621 \\
(0.0567)\end{array}$ \\
\hline $\begin{array}{l}\text { Alternative Definitions of Treated County } \\
\text { Require all entities in the country to pass referendum }\end{array}$ & $\begin{array}{c}0.1010 * * * \\
(0.0124)\end{array}$ \\
\hline Any entity in the county passes the referendum & $\begin{array}{c}0.1460 * * * \\
(0.0107)\end{array}$ \\
\hline
\end{tabular}

Notes: See notes to Table 2 and 3 for further details of estimation. Control industry is all other non-retail industry (the same control used to produce estimation results in Tables 2 and 3 ). 
Figure 1. Determining rule for classifying county as treated or control.

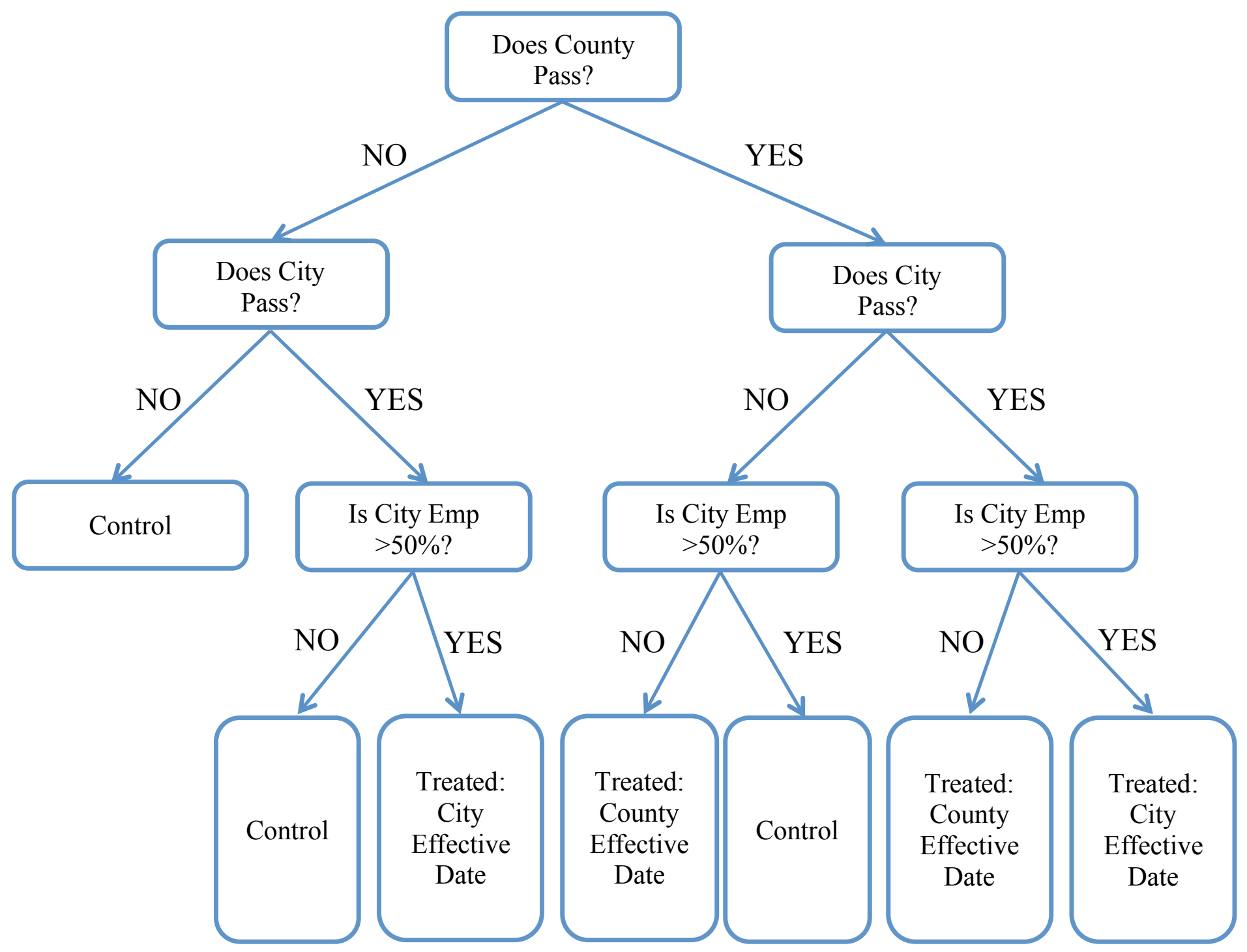

Notes: "City Emp" may refer to multiple cities within the county. 
Figure 2. Map of Georgia counties by date of removal of Sunday alcohol sales restrictions.

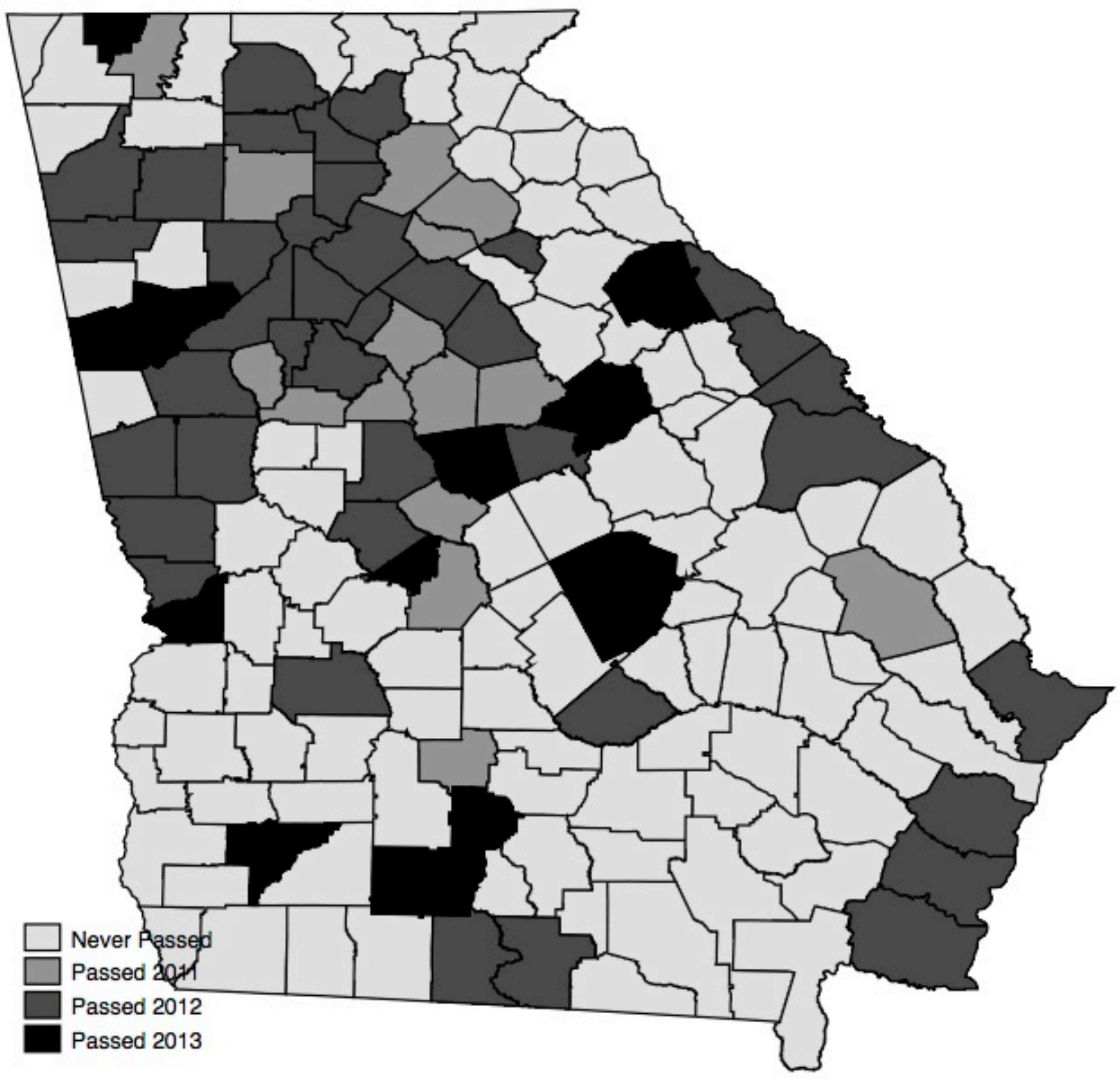

